\title{
Notch receptors in GtoPdb v.2021.2
}

\author{
Thiruma V. Arumugam ${ }^{1}$ and Christopher Sobey ${ }^{2}$
}

1. National University of Singapore, Singapore

2. Monash University, Australia

\begin{abstract}
Aberrant Notch signalling is implicated in a number of human cancers [18, 26, 13, 21], and there is intense pharmaceutical activity being directed towards achieving clinically effective Notch pathway inhibition $[7,16]$.
\end{abstract}

\section{Contents}

This is a citation summary for Notch receptors in the Guide to Pharmacology database (GtoPdb). It exists purely as an adjunct to the database to facilitate the recognition of citations to and from the database by citation analyzers. Readers will almost certainly want to visit the relevant sections of the database which are given here under database links.

GtoPdb is an expert-driven guide to pharmacological targets and the substances that act on them. GtoPdb is a reference work which is most usefully represented as an on-line database. As in any publication this work should be appropriately cited, and the papers it cites should also be recognized. This document provides a citation for the relevant parts of the database, and also provides a reference list for the research cited by those parts. For further details see [6].

Please note that the database version for the citations given in GtoPdb are to the most recent preceding version in which the family or its subfamilies and targets were substantially changed. The links below are to the current version. If you need to consult the cited version, rather than the most recent version, please contact the GtoPdb curators.

\section{Database links}

Notch receptors

https://www.guidetopharmacology.org/GRAC/FamilyDisplayForward?familyId=914

Introduction to Notch receptors

https://www.guidetopharmacology.org/GRAC/FamilyIntroductionForward?familyId=914

Targets

notch receptor 1

https://www.guidetopharmacology.org/GRAC/ObjectDisplayForward?objectId=2861

notch receptor 2

https://www.guidetopharmacology.org/GRAC/ObjectDisplayForward?objectId=2859

notch receptor 3

https://www.guidetopharmacology.org/GRAC/ObjectDisplayForward?objectId=2860

notch receptor 4

https://www.guidetopharmacology.org/GRAC/ObjectDisplayForward?objectId=2862

\section{References}

1. Agrawal N, Frederick MJ, Pickering CR, Bettegowda C, Chang K, Li RJ, Fakhry C, Xie TX, Zhang $\mathrm{J}$ and Wang J et al.. (2011) Exome sequencing of head and neck squamous cell carcinoma reveals inactivating mutations in NOTCH1. Science 333: 1154-7 [PMID:21798897]

2. Al-Hussaini H, Subramanyam D, Reedijk M and Sridhar SS. (2011) Notch signaling pathway as a therapeutic target in breast cancer. Mol Cancer Ther 10: 9-15 [PMID:20971825]

3. Astudillo L, Da Silva TG, Wang Z, Han X, Jin K, VanWye J, Zhu X, Weaver K, Oashi T and Lopes PE et al.. (2016) The Small Molecule IMR-1 Inhibits the Notch Transcriptional Activation 
Complex to Suppress Tumorigenesis. Cancer Res 76: 3593-603 [PMID:27197169]

4. Belver L and Ferrando A. (2016) The genetics and mechanisms of T cell acute lymphoblastic leukaemia. Nat Rev Cancer 16: 494-507 [PMID:27451956]

5. Bhanushali AA, Babu S, Thangapandi VR, Pillai R, Chheda P and Das BR. (2010) Mutations in the HD and PEST domain of Notch-1 receptor in T-cell acute lymphoblastic leukemia: report of novel mutations from Indian population. Oncol Res 19: 99-104 [PMID:21302811]

6. Buneman P, Christie G, Davies JA, Dimitrellou R, Harding SD, Pawson AJ, Sharman JL and Wu Y. (2020) Why data citation isn't working, and what to do about it Database $\mathbf{2 0 2 0}$ [PMID:32367113]

7. Fabbro D, Bauer M, Murone M and Lehal R. (2020) Notch Inhibition in Cancer: Challenges and Opportunities. Chimia (Aarau) 74: 779-783 [PMID:33115560]

8. Garg V, Muth AN, Ransom JF, Schluterman MK, Barnes R, King IN, Grossfeld PD and Srivastava D. (2005) Mutations in NOTCH1 cause aortic valve disease. Nature 437: 270-4 [PMID:16025100]

9. Grabher C, von Boehmer H and Look AT. (2006) Notch 1 activation in the molecular pathogenesis of T-cell acute lymphoblastic leukaemia. Nat Rev Cancer 6: 347-59 [PMID:16612405]

10. Gurney Al, Hoey TC, Bruhns MF and Axelrod FT. (2014) Notch1 receptor binding agents and methods of use thereof Patent number: US20140011271A1.

11. Gurney AL, Hoey TC, van der Horst ETH, Sato AK, Liu YC, Bruhns MF and Lewicki JA.. (2012) Antibodies to notch receptors. Patent number: US8226943 B2.

12. Kangsamaksin T, Tattersall IW and Kitajewski J. (2014) Notch functions in developmental and tumour angiogenesis by diverse mechanisms. Biochem Soc Trans 42: 1563-8 [PMID:25399571]

13. Lefort K, Mandinova A, Ostano P, Kolev V, Calpini V, Kolfschoten I, Devgan V, Lieb J, Raffoul W and Hohl D et al.. (2007) Notch1 is a p53 target gene involved in human keratinocyte tumor suppression through negative regulation of ROCK1/2 and MRCKalpha kinases. Genes Dev 21: 562-77 [PMID:17344417]

14. Lehmann BD, Pietenpol JA and Tan AR. (2015) Triple-negative breast cancer: molecular subtypes and new targets for therapy. Am Soc Clin Oncol Educ Book 35: e31-9 [PMID:25993190]

15. McBride KL, Riley MF, Zender GA, Fitzgerald-Butt SM, Towbin JA, Belmont JW and Cole SE. (2008) NOTCH1 mutations in individuals with left ventricular outflow tract malformations reduce ligand-induced signaling. Hum Mol Genet 17: 2886-93 [PMID:18593716]

16. Moore G, Annett S, McClements L and Robson T. (2020) Top Notch Targeting Strategies in Cancer: A Detailed Overview of Recent Insights and Current Perspectives. Cells 9 [PMID:32575680]

17. Nagamatsu I, Onishi H, Matsushita S, Kubo M, Kai M, Imaizumi A, Nakano K, Hattori M, Oda Y and Tanaka M et al.. (2014) NOTCH4 is a potential therapeutic target for triple-negative breast cancer. Anticancer Res 34: 69-80 [PMID:24403446]

18. Ntziachristos P, Lim JS, Sage J and Aifantis I. (2014) From fly wings to targeted cancer therapies: a centennial for notch signaling. Cancer Cell 25: 318-34 [PMID:24651013]

19. Puente XS, Pinyol M, Quesada V, Conde L, Ordóñez GR, Villamor N, Escaramis G, Jares $P$, Beà $S$ and González-Díaz M et al.. (2011) Whole-genome sequencing identifies recurrent mutations in chronic lymphocytic leukaemia. Nature 475: 101-5 [PMID:21642962]

20. Rossi D, Rasi S, Fabbri G, Spina V, Fangazio M, Forconi F, Marasca R, Laurenti L, Bruscaggin A and Cerri M et al.. (2012) Mutations of NOTCH1 are an independent predictor of survival in chronic lymphocytic leukemia. Blood 119: 521-9 [PMID:22077063]

21. Sjölund J, Johansson M, Manna S, Norin C, Pietras A, Beckman S, Nilsson E, Ljungberg B and Axelson H. (2008) Suppression of renal cell carcinoma growth by inhibition of Notch signaling in vitro and in vivo. J Clin Invest 118: 217-28 [PMID:18079963]

22. Sorrentino C, Cuneo A and Roti G. (2019) Therapeutic Targeting of Notch Signaling Pathway in Hematological Malignancies. Mediterr J Hematol Infect Dis 11: e2019037 [PMID:31308913]

23. Stittrich AB, Lehman A, Bodian DL, Ashworth J, Zong Z, Li H, Lam P, Khromykh A, Iyer RK and Vockley JG et al.. (2014) Mutations in NOTCH1 cause Adams-Oliver syndrome. Am J Hum Genet 95: 275-84 [PMID:25132448]

24. Stransky N, Egloff AM, Tward AD, Kostic AD, Cibulskis K, Sivachenko A, Kryukov GV, Lawrence MS, Sougnez C and McKenna A et al.. (2011) The mutational landscape of head and neck squamous cell carcinoma. Science 333: 1157-60 [PMID:21798893]

25. Tran IT, Sandy AR, Carulli AJ, Ebens C, Chung J, Shan GT, Radojcic V, Friedman A, Gridley T and Shelton A et al.. (2013) Blockade of individual Notch ligands and receptors controls graftversus-host disease. J Clin Invest 123: 1590-604 [PMID:23454750]

26. Vilimas T, Mascarenhas J, Palomero T, Mandal M, Buonamici S, Meng F, Thompson B, Spaulding C, Macaroun S and Alegre ML et al.. (2007) Targeting the NF-kappaB signaling pathway in Notch1-induced T-cell leukemia. Nat Med 13: 70-7 [PMID:17173050]

27. Villamor N, Conde L, Martínez-Trillos A, Cazorla M, Navarro A, Beà S, López C, Colomer D, 
Pinyol M and Aymerich M et al.. (2013) NOTCH1 mutations identify a genetic subgroup of chronic lymphocytic leukemia patients with high risk of transformation and poor outcome. Leukemia 27: 1100-6 [PMID:23295735]

28. Weng AP, Ferrando AA, Lee W, Morris 4th JP, Silverman LB, Sanchez-Irizarry C, Blacklow SC, Look AT and Aster JC. (2004) Activating mutations of NOTCH1 in human T cell acute lymphoblastic leukemia. Science 306: 269-71 [PMID:15472075]

29. Yuan X, Wu H, Xu H, Xiong H, Chu Q, Yu S, Wu GS and Wu K. (2015) Notch signaling: an emerging therapeutic target for cancer treatment. Cancer Lett 369: 20-7 [PMID:26341688] 